\title{
Technological Democratization: The Potential Role of ICT in Social and Political Transformation in China and Beyond
}

\author{
Neal A. Palmer \\ Dept. of Human \& Org. Development \\ Peabody College \#90, Vanderbilt University \\ Nashville, TN 37203-5701 USA \\ E-mail: neal.a.palmer@gmail.com \\ Douglas D. Perkins \\ Dept. of Human and Organizational Development \\ Peabody College \#9o, Vanderbilt University \\ Nashville, TN 37203-5701 USA \\ E-mail: d.perkins@vanderbilt.edu
}

\begin{abstract}
This paper seeks to understand the role of the Internet and information and communications technology (ICT) in potential democratic movements. We propose an ecological model of technological development and democratization which recognizes that change can occur (1) at individual as well as social levels; (2) on a continuum from oppression to freedom; and (3) in multiple social spheres. Using case studies from China, we suggest that ICT might facilitate democracy on account of its potential transformations and efficiencies in terms of individuals' relationships to knowledge and information; governments; persons, groups, and nongovernmental organizations; and work and traditional social roles.
\end{abstract}

\section{Keywords}

communications technology, developing world, information technology, e-government, political reform, globalization

\section{Introduction}

Globalization has been advanced by the rapid development and spread of technology and communication tools across the globe (Stiglitz 2003). Developing countries have become integrated into worldwide production systems, as components of these technological products are manufactured on global assembly lines (Everett 1998). Such developments have increased interest in 
the potential effects of ICT access on social and political processes, particularly in less democratic, less developed countries (see Avgerou 2008, for instance). Direct foreign investment has been shown to increase with democratization, and such investment, although being dependent on a minimal level of information technology infrastructure (Addison and Heshmati 2004), also effects rapid technological gains ( $\mathrm{Li}$ and Resnick 2003). In turn, the increasing presence of technological innovations carries with it the potential for what might be termed technological democratization. Further, increasingly decentralized, affordable, and mobile technologies may be eliminating the need for substantial infrastructural investments of the type that have led to economic and social transformations in India and elsewhere (Bowonder et al. 1993), creating the potential for economic development and democratization even without direct foreign investment.

All of these trends point to the interdependencies among the different dimensions of development and the key role of technological change in promoting each of the other dimensions. ICT-related innovation and growth represent a particularly important form of physical infrastructure development and one that is arguably even more closely tied to political, economic, and socio-cultural development than are roads, bridges, irrigation, and indoor plumbing. ICT is obviously critical to trade and other economic activity and to other, particularly knowledge-dependent dimensions of development such as healthcare, disease prevention, and education (Castells 1999; Chaudry et al. 2006). As such, ICT's impact on social capital development, through virtual communities, social support, and information sharing, is generally assumed to be both strong and positive. It can connect previously marginalized persons in empowering ways, for example (Warschauer 2000); however, at the same time it can serve as a force of cultural hegemony and homogenization (Holton 2000). Furthermore, its effects are susceptible to exaggeration, as will be addressed throughout this paper.

More specifically, our paper explores these effects of local and global social connectivity, but mainly in relation to their implications for democratization or political development. Thus, technological development is a vital and direct ingredient for all other forms of development, but its influence on democratization is especially important, as political development is often, but not always (cf. China), related to the other dimensions of development mentioned above. For example, a politically free media communications sector (enhanced by ICT) is important to facilitate commercial activity at both the consumer and investment levels. Legitimate, uncorrupted courts and criminal justice systems (supported by the most accurate intelligence and other information) are essential for trust in credit markets at all levels. Free trade laws and treaties and 
relatively open borders and immigration and work visa policies are obviously conducive to the flow of workers as well as goods and services, which would not be possible without the modern global ICT system. Yet the acid test of political development is free elections, and here the role of ICT in connecting democratization with other development dimensions has been less consistent, which we will discuss. Thus, the real potential of ICT rests not merely in facilitating development that replicates and mimics U.S. and international markets, but in initiating social and political, and not just financial, change (Silva and Westrup 2009).

Journalists and academics attending to the dramatic democratization protests in the early months of 2011 in Tunisia, Egypt, and throughout the Middle East have commonly acknowledged widespread Internet access as a tipping point or lit match to the longstanding fuel of large unemployed and underemployed youth populations and corrupt authoritarian regimes in that part of the world. Elsewhere, Castells (1997) has documented how Chiapas rebels used ICT to oppose the Mexican central government, and Hill and Sen (2005) have documented similar tactics to oppose the Suharto regime in Indonesia. Such emergent movements give some credence to what Avgerou (2010) describes as "disruptive transformation," which is theorized to emerge as a result of tense inequalities. As Avgerou (2010) suggests, however, such a framework tends to overlook the underlying philosophy behind greater ICT access, which relies on Western logic in maintaining efficiency and power. In fact, the role of Facebook, Twitter, and Google was perhaps overstated by mass media commentators who ignored other economic factors, such as inequality and food price shocks, providing evidence of what web activist Morozov (2011) has criticized as a belief among "cyber utopians." In analyzing possible contributing factors in the recent mass political uprisings in North Africa and the Middle East, the New York Times (Blow 2011) published a table showing that a combination of moderately high Internet penetration, low median age of population, marginally high unemployment and income inequality, and high local cost of food may have helped the democracy movements in Tunisia and Egypt to mobilize and succeed. ${ }^{1}$ Although no other country in the entire region has exactly the same constellation of factors, a few exceptions are worth noting. Most dramatically, two of the countries with the lowest Internet penetration-Yemen and Libya ( $1.8 \%$ and $5.5 \%$ respectively, as compared to Egypt with $21.2 \%$, Tunisia with $34 \%$, and the U.S. with $77 \cdot 3 \%$ - also experienced major democratic uprisings (although one could argue that they would have been more successful, and

\footnotetext{
1 Freeland (2011) similarly analyzed global data on Internet penetration, political oppression, corruption, and food prices, and found that, based on just those four variables, Libya, Algeria, Egypt, Russia, Uzbekistan, Azerbaijan, and Venezuela were among the most vulnerable countries in the world.
} 
perhaps less bloody, with greater Internet access). Yet Bahrain, with one of the highest levels of Internet use in the world at 88\%, experienced major demonstrations that also, ultimately, did not succeed, at least not yet. Similarly, Shirazi et al. (2011) point to China specifically as an under-performer in the process of democratization due to its continued censorship of the Internet and ICT, despite the dramatic growth of the sector over the past decade. Thus, it seems that Internet penetration is neither necessary to start a democratic revolution nor sufficient to complete one, particularly when Internet access can be shut down by the government. Such contradictions also reveal the need for a model of technological democratization at multiple levels, which we propose here.

Even before those recent events, numerous authors had noted how this rapid networking of people through ICT has enabled the development of international resistance movements and coordinated mass demonstrations across the globe (Juris 2008; Keck and Sikkink 1997). Digital democracy theorists posit that ICT complements democracy by enhancing communication between persons and groups, encouraging political participation by leveling barriers to it, and permitting an expanded array of ideas to shape public discourse. Wilson (2009) suggests that features of digital media - including participation, openness, and an active role in knowledge/content creation - are closely related to essential features of democracy_-including competition, open and accessible spaces, and rights, responsibilities, and roles in political functioning. Whereas Wilson (2009) rejects a technological determinism that views democracy as the inevitable outcome of the Internet, as well as a determined technology view that regards technology only as an effect of a particular context, Yang (2009) instead suggests that the medium facilitates spaces for contention and criticism. Thus, the online medium generates a new form of activism, with its own particular characteristics, primarily oriented around activities of contention.

We argue that ICT has also fundamentally changed the politics of more local spaces through its resulting efficiencies in four important areas: (1) accessing knowledge, (2) communicating with governments, (3) connecting to nongovernmental organizations and other individuals locally, and (4) transforming traditional labor roles (and, as a result, power). By extension, we suggest that ICT changes relationships between individuals and their entire personal worlds, including their relationships not only to information, but to their governments, their families and friends, and other persons and organizations with similar interests/goals, including virtually unlimited opportunities and connections that simply would not exist for them without ICT. Together, these create the potential for individual and social transformation, and ultimately, perhaps, democratization.

Our proposed ecological model of technological development and democratization (see Figure 1) adapts Christens and Perkins' (2008) comprehensive 
three-dimensional framework analyzing power dynamics across four domains of capital and three levels. Our model highlights the role of technology (among other forms of physical capital) in democratization. It acknowledges the relevance of particular information and communication technologies to political, financial, and social forms of capital and to oppression and processes of liberation and practical democracy. Unlike Christens and Perkins' (2008) model, it does not highlight different levels of analysis or intervention because technology serves to connect people and institutions in ways that tend to blur levels. Instead, our model highlights the above spheres of efficiency in technology's power to connect people to knowledge, government, groups, and work and other roles. For each of these potential areas of efficiency, technology can enable further oppression, a transformational democratization, or, more likely, a liberatory process that lies somewhere in between. Our purpose is to reinforce the notion that although a particular technology might be oriented toward a specific purpose, its ultimate utility in transformation can only be understood in context and in practice. We provide examples from China to illustrate the role of technology in these four areas, although we also augment the discussion with additional examples, when appropriate, in order to provide more nuanced understandings of our assertions.

\section{Figure 1 Ecological Model of Technological Development and Democrati- zation (adapted from Christens \& Perkins 2008)}

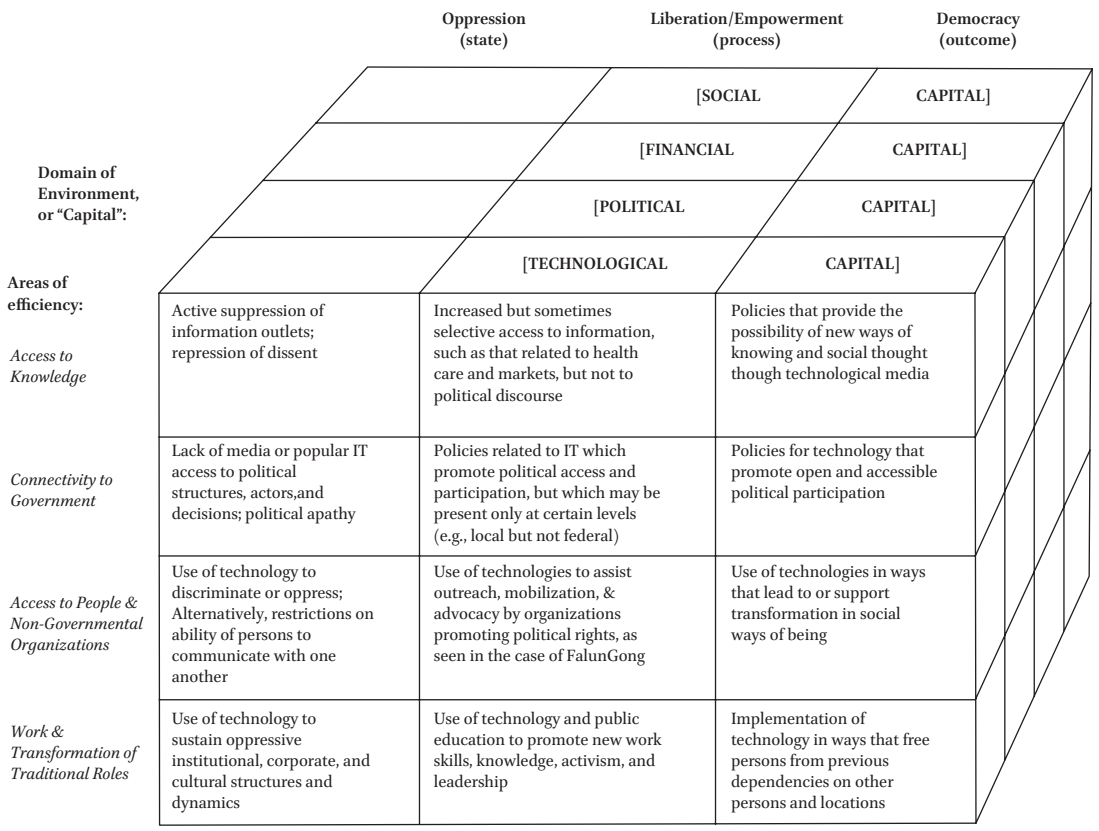




\section{Areas of Efficiency}

\subsection{Efficiencies in Access to Knowledge}

The Internet has enabled the assembly of the greatest concentration of knowledge in history and, thus, naturally has the potential to undermine power differentials that have been predicated on exclusionary access to knowledge. Persons with access to the Internet can learn about issues directly affecting them, such as environmental degradation, disease rates, and government inefficiency, as well as about strategies for responding to these concerns. For instance, increased access to health knowledge has the potential to improve the health of populations in developing countries by both increasing access to information as well as creating forums for disseminating more locally relevant information (Edejer 2000).

China provides an important case study of the democratizing effects of technology. One aspect that makes the case interesting is the startling rapidity of China's technological development, which is clearly and closely linked with its economic miracle of the past 30 years; at the same time, the Communist Partycontrolled government strenuously resists, or at least slows to a crawl, democratic political development. But ICT has led Chinese development in other areas. Ulrich (2004) has documented, for example, that rural villagers in China utilize community Internet centers to treat illnesses. Recognizing disparities between urban and rural education and difficulties faced by rural residents in accessing schools, China has also sought to improve education in rural areas (Zhu 2006). In other contexts, displaced or transitory persons, who otherwise would not have access to the fundamental right of education, may be empowered by accessing knowledge through distance learning programs (Madon 2000). By using ICT to create more educated publics, these governments are also perhaps laying the cornerstones for future democratic movements. Similarly, the Internet may enable marginalized persons, such as indigenous populations and women, to respond to other forms of oppression by enabling them to create widely disseminated knowledge for the first time (Bonder 2002; Madon 2000). Fischer (2001) has documented how the development of a unified Mayan alphabet fomented ethnically based political action by permitting common cultural narratives of resistance, which has been further promoted through the development of computer-aided Mayan print systems; moreover, the distribution of activist work through email has helped solidify the movement internationally.

One project to expand community Internet access in rural China found that, even though many households already owned televisions and telephones, the construction of a town information and Internet access centre improved 
farming practices and enabled farmers to find better price information for both selling and purchasing (Ulrich 2004); Zhu (2006) has observed similar benefits for farmers in other areas of China. Interestingly, entire geographic areas may benefit from such investments even if not all residents in an area utilize the technologies, for simply being networked with another person who has access to and fluency with the technologies may confer the same information and benefits as accessing them oneself; thus, even small investments in technology may enhance entire communities' qualities of life (Ulrich 2004). Importantly, rural residents who gained access to the Internet via the community centre also rated the information they obtained from the Internet as much more reliable than that which they obtained from other sources. Similar results have been found for a community technology centre for farmers in Uganda, helping them increase their yields and improve their qualities of life (Leahy and Yermish 2003).

On the other hand, the potential of the Internet for emancipatory purposes must be understood in relation to the divide that exists between the North and South and also within countries (Keniston 2004). Access to and the emancipatory potential of the information amassed through the Internet is restricted by language, as the principal language of the Internet has been and remains English (Abbott 2001; Keniston 2004). Perhaps more important to the Chinese case are internal digital divides, which exist for financial as well as demographic reasons. In 2000, nearly $20 \%$ of China's Internet subscribers lived in Beijing, and another $11 \%$ in Shanghai-two cities which, respectively, housed just $1.5 \%$ and $1.7 \%$ of China's total population (Wilson 2004). As of 2005, almost $60 \%$ of web users lived in wealthier, eastern coastal areas, and the connectivity gap in the most connected area (Beijing, 27.6\%), was more than 10 times what it was in the least connected province, Guizhou (2.5\%). Other rural and inland (and less economically developed) provinces generally had connection rates under $7 \%$ (Zhu 2006).

With the advent of Internet-accessible cell phones, this divide is narrowing, however. As of December 2008, nearly 650 million people, or $50 \%$ of the population (Ministry of Industry and Information Technology of People's Republic of China 2008; Williams 2009) owned mobile phones. Although access remains marked by economics and geography-nearly $70 \%$ of residents on the east coast had phones, with $40 \%$ of residents in inland provinces having mobile phones and $37 \%$ of western province residents - this represents a remarkable jump over the $20 \%$ of residents who had mobile phones in 2003 (Zhu 2006). As costs continue to decrease, diffusion has increased even among the most economically marginalized citizens (Chiu 2009). Between 2002 and 2006 in major east-coast migrant destinations, for instance, the average monthly expense of 
mobile phones decreased by $50 \%$, and diffusion among migrant workers grew by $25 \%$; Internet costs decreased by $11 \%$, and diffusion increased by $27 \%$.

Overall access to the Internet is clearly increasing. As of 2010, 420 million users, or $32 \%$ of the population, were Internet users (China Internet Network Information Center 2010). Much of this growth has come via Internet cafes. By 2008, more than 70 million people used Internet cafes, or $35 \%$ of the total national Internetusing population. In addition, the percentage of users with home access increased over the past decade from $50 \%$ to $70 \%$ (Chiu 2009). Although netbars remain prohibitively expensive for much of the country (Abbott 2001), they have transformed the Internet from a tool available to the elite, to one accessible to working-class users (Chiu 2009). That the medium is now available to people even at the lowest ends of the economic spectrum (at least in urban areas) suggests great potential for change across every level of society.

Whereas the expansion of ICT does open up developing areas to larger bodies of knowledge, it also exposes and integrates them into potentially exploitative neo-colonial systems of production (Ya'u 2004). Indeed, countries such as Jordan and Singapore have focused on ICT development with the explicit goal of enhanced competition in global markets (Al-Jaghoub and Westrup 2006). Newly introduced technologies therefore do little to challenge oppressive structures without explicit attention to this purpose. Although expanded production systems have brought more women into the workforce, for instance, they have generally funneled them into unskilled and undervalued work (Mitter and Rowbotham 2000) because they rely on a Western consensus that is insufficiently critical of the belief in technology as a universally positive agent of change (Silva and Westrup 2009). Contexts exclusionary to women, then, may not be altered without explicit effort to integrate these women into economic and social systems, such as woman-focused small enterprises and microcredit programs (Platt and Wilson 1999). Freire (1970) embraced the role of media literacy in empowering individuals against oppression, using slide projectors to display film slides to visually represent peasants' lives and enable a collective learning, which could then be interrogated and reassembled in new terms. Nonetheless, Freire (1970) argued that technology and electronic media exhibited tendencies to dehumanize and alienate traditional cultures if not intentionally engaged to accommodate diverse, historically suppressed communities (Kahn and Kellner 2007).

In addition, developing countries routinely appropriate ICT designed for the developed world, and they do so in ways that do not replicate the intended uses of the technology, whether those are liberatory or not (Heeks 2002). Reliance on Western models that emphasize liberalization and privatization of technological development is unlikely to benefit persons equally, and its 
effects are likely to be centered in (urban) areas that already possess baseline levels of infrastructure, thus potentially excluding large groups of (rural) people yet again (Bhuiyan 2004). Accordingly, Avgerou (2010) warns that ICT improvements rarely challenge large-scale socio-political structures, and thus any change that results might be concentrated more at individual and meso levels than more broadly. To the extent it is used only self-interestedly or to perpetuate ideological divides, ICT may do little to promote larger structural change (Wilson 2009). Some may even be appropriated specifically for the maintenance of these boundaries; for instance, ICT has been remarkably effective at fomenting nationalist discourse and anti-Japanese rhetoric in China (Yang 2009). Therefore, without attention to these details, introduced technologies ultimately run the risk of reproducing existing hierarchies (Keniston 2004).

The emancipatory potential of ICT must also be understood in relation to intentional restrictions imposed by governments even in the presence of ICT (Abbott 2001). Although prominent leaders, including former US President Bill Clinton, have pointed to the Internet as a definitive resource for democracy, Wilson (2004) remains much more cautious. He argues that, although the Internet supports grassroots movements, it also supports the functions of central government. Similarly, Drezner (2005) suggests that the Internet often reinforces the existing dynamic between citizen and state, rather than as an unconditionally democratizing force. Drawing on the example of access to health information, one can point to efforts to suppress the release of information in the early failure of China to address the SARS outbreak; such decisions were driven by a fear of social unrest and economic losses, again suggesting how ICT developments often uphold rather than challenge dominant economic and political systems (Zheng 2005). The government continues to restrict Internet use and information in the name of social stability, and perhaps more truthfully, to protect its own interests (Labiad 2006; Wilson 2004). Oddly, restrictions on personal freedom may have actually increased in China since the advent of the Internet (Lagerkvist 2010). With the arrival of the 1980 s and policies initiated by Deng Xiaoping, the national news moved to a model that reported only the positive, uncontroversial stories, supporting an attempt to create a "harmonious society." Even though the web offers a much greater range of information for consumers, the government has invested heavily in the online presence of official news organizations (e.g., Xinhua) in an attempt to maintain them as official drivers of national discourse (Wilson 2004). In addition, its strong investment in China Telecom has made it difficult for Internet service provider (ISP) start-ups to gain a foothold, thereby allowing it to maintain a firmer control on the information traveling through Internet portals (Wilson 2004). 
Of course, capitalist democracies are guilty of censorship as well, often in less overt ways. Yahoo was recently criticized for blocking emails regarding the Occupy Wall Street protests in New York (Fang 2011). The Murdoch scandals in London and the US (e.g., Entous 2011), and the cozy relationship between reporters and Bush administration officials used to justify the war in Iraq (e.g., Moore 2004) have demonstrated just how interdependent the two entities can be, raising serious doubts as to the veracity of information presented to the public. At times in recent years, the US government has even taken a central role in undermining the credibility of critics (e.g., MacAskill 2007). Thus, censorship must be understood not along a binary between a functioning multiparty democracy and a centralized, autocratic regime, but rather along a continuum of the ability of various forces-government, business, etc.- to limit access to and the spread of information.

Even with the caveat that the mass of information now available over the Internet is still heavily censored in China, and even though increasing use of the Internet has as of yet failed to spark a democratic revolution in China, we argue nonetheless that the resulting efficiencies in accessing knowledge are fundamentally changing people's relationship to that knowledge. Even if information is subject to censorship, the fact that people have a more active role in the spread of knowledge has clear implications for agency in other social spheres (Labiad 2006). Over time, the content of that information will change in addition to the changes in relationship already taking place. The medium clearly supports the exchange of ideas across small and great expanses; those ideas may not necessarily be democratic ones, but as the following sections demonstrate, they are changing the long-standing expectations of citizens regarding their government, their peers, and themselves.

\subsection{Efficiencies in People's Connectivity to Government}

Increased access to information has aided the development of e-government initiatives (Saidi and Yared 2002): in short, greater governmental accountability and transparency. E-government can refer to such simple steps as making information available online to dispensing essential government services online. Seifert and Petersen (2002) outline e-government progression from simple presence, to interaction and transaction, and finally to transformation. Nonetheless, the logic behind such initiatives must be challenged. Bloomfield and Hayes (2009) point to e-government initiatives as an extension of privatization and rationalization efforts, even if they are not yet recognized as such by some of the institutions involved; thus, although the customer is often highlighted as the beneficiary of such projects, they might also result in a decrease in services and more regimented roles for employees. 
Whereas such steps have often been framed in terms of efficiency and convenience in the West (Seifert and Petersen 2002), they may have more transformative effects in developing countries because they alter the relationships between governments and citizens. For instance, technology has been used in developing countries, along with greater attention and commitment to international law, to counter the potential for corruption (Backus 2001). This new form of governing has transformed the relationship between state and citizens, and state and business, and has enabled direct communication between these parties. Citizen assistance call centers in developing countries help citizens navigate public service systems, resulting in more responsive, democratic governments (Ndou 2004). Whereas the prior lack of access to government encouraged the use of bribes to achieve even relatively modest tasks, technology-based systems have allowed citizens to sidestep these intermediate actors (Mahmood 2004). In Argentina, for example, provincial budgets, contracts, and payroll information must be posted online, and similar measures have recently been introduced in parts of Africa (Schroth and Sharma 2003) and Asia (Mahmood 2004). Such measures have also helped overturn an antidemocratic regime in Indonesia and thus resulted in strong resistance movements in Malaysia (Abbott 2001). These efforts have been observed in China as well. In 1998 , the central government launched "Government On Line," aiming to have $60 \%$ of government organizations online within the year, with the intention to describe the department's function, provide important documents, and offer relevant news. Many departments began offering the opportunity to send letters or messages to officials in those departments as well. Although such efforts can also be interpreted with more sinister intentions (e.g., to retain legitimacy rather than offer true democracy), the program has changed the relationships between citizen and governments, with citizens now expecting more from their governments (Zhu 2006). Despite this progress, China and other repressive regimes (e.g., North Korea, Myanmar, Iran) continue to operate from a top-down perspective that views government as the official arbiter of information. Mahmood (2004) asserts that the success of government reform efforts is dependent upon regime type as well as variables such as political will, agency of local officials, and immediacy of crisis. Similarly, Morozov (2011) warns that political, cultural, and sociological considerations must be evaluated to determine the potential impacts of technology developments. Reform will be more successful the more democratic the state, although even "minimal democracies" can achieve some success in reform measures, particularly if local officials are granted some autonomy from centralized decision-making (Mahmood 2004).

Still, the Internet may represent a new kind of public sphere (Wang 2008), which demands different relationships between citizens and government. This 
public sphere, an essential cornerstone of democracy, offers the opportunity for the true exchange of ideas (Labiad 2006; Wang and Bates 2008). Media consumers have become media producers, allowing them a greater role in setting the agenda rather than simply responding to it, thus making them agents of political change. ICT expansion has permitted citizens a greater role in investigative journalism, and citizens have recognized their ability on the Internet to access and produce a much wider range of information than is available through other mediums (Wang 2008). Yang (2009) argues that the Internet has primarily increased the possibility of contention, and for this reason has facilitated activism. Along with text messaging, online petitions, bulletin boards, and outright hacking, Yang (2009) emphasizes the potential of blogging in this new medium of contention. Indeed, of the 420 million Internet users in China by 2010 (China Internet Network Information Center 2010), more than halfand almost $20 \%$ of the total population-identified themselves as bloggers. Bloggers also represent key constituent groups: two-thirds of middle school and primary students identify themselves as bloggers; more than four-fifths of college students; half of white-collar workers; and half of rural migrant workers (Lagerkvist 2010). Many of these persons attain celebrity status akin to what mainstream journalists in the West command. Authorities are forced to respond to blog posts, and although they retain the power to delete controversial postings, they must do so in a much more public venue and in ways that might provoke public backlash (Lagerkvist 2010). Furthermore, the ability to preserve posts through screenshots means that protests messages can continue to live despite efforts at censorship (Wines 2009). Bloggers thus occupy an increasingly prominent role in changing and pushing against social norms.

One of the more prominent examples of this contention can be seen in blogs used to criticize corrupt local governmental officials and attempt to hold them accountable. For many such officials, these efforts have even resulted in lengthy prison sentences. Beijing Professor Hu Xingdou refers to this contemporary use of the Internet as "disguised accountability," dependent on citizens rather than more traditional means of democratic governments (Richburg 2009). Although this potential arises only because of the failure of the government to discipline itself, the Internet has made citizen journalism something to be feared, with its demands potentially backed by masses of people (Lagerkvist 2010).

Such concessions allow the central government to claim transparency and freedom when confronted by accusations of oppression, but some latitude in ignoring larger suppressions on freedom (Morozov 2011). For instance, governments of North Korea and Myanmar permit debate on such topics as environmental degradation, but block discussion of human rights abuses (Morozov 2011). In a particularly sinister move, China may permit a handful of critical blogs so as to gain intelligence about current social tensions and about their 
primary antagonists (Morozov 2011). Similarly, the government may provide some mechanisms for social expression-such as online forums, comments, blogs, and chat rooms - so as to increase its legitimacy and the appearance of responsiveness to the public (Wang 2008). The country has often permitted online protests to persist, but they tend to more severely restrict them once they begin to target national issues or officials. The swift response of the government to the 2009 uprising in Xinjiang illustrates just how powerful the central information apparatus still is. The ability of the government to demand censorship compliance from Google, and eventually its exit from the Chinese market, further illustrates this point (Lagerkvist 2010). China has restricted foreign investments in its ICT sector out of fears that it could undermine its national autonomy and the authority of the government (Guthrie 2005; Wilson 2004). In addition, China maintains its own versions of popular websites like Facebook and Twitter that it can more easily control (Richburg 2009). This centralization in turn allows it to observe potential social tensions and the ability to respond in targeted ways (Lagerkvist 2010).

Whatever motives are present, participation in the market system normally requires increased access to information in order to be successful, which may explain China's economic success over other repressive regimes like North Korea and Libya. China has realized the importance of ICT development and industry to global economic competition, and thus has poured money into the sector. Although the evidence here suggests continued regulation of information to the fullest capacity possible, increasing market forces have nonetheless decreased the regulatory power of the central authorities (Yang 2009). This has created the space for a new, more public and more vocal criticism of government attempts at censorship. By referring to being censored as being "harmonized" (Lagerkvist 2010: 127), bloggers directly challenge official government ideology that positions restraint and restriction-for the sake of social "harmony" - above individual freedoms. Dissidents respond to censorship by reconfiguring blocked phrases or messages, such as the translation of the activist's name "Liu Xiaobo" to "LXB" rather than to traditional Chinese characters (Joyce 2010, 2011). In another example, online activists responded to the government's crackdown on Internet pornography by giving life to an Internet creature called cao ni ma, which can be read either as "grass-mud horse" or as "fuck your mother" (Lagerkvist 2010). One activist created a video contained entirely within World of Warcraft to satirize the government's attempt at "harmonization" through censorship (Bishop 2010; Stout 2010). Other documented means of defying efforts at censorship and Internet access include accessing the Internet via unregistered portals (Guthrie 2005), hiding digital trails and failing to register online activity (Wilson 2004). Although such 
tactics can be overcome by the government, and dissidents are forced to constantly produce new configurations of subversion, they nonetheless represent new sites of agency in highly censored environments, which challenge the rationale of that censorship altogether.

Importantly, these efforts are changing expectations of the government across broad swaths of society. One Chinese newspaper noted, in response to citizens questioning the official government position on one contentious event, that "the era when people blindly believe what the government tells them is over. Likewise, the era when the people are too afraid to speak out is also over" (Duerme, 2007, cited in Wang, 2008: 16). One recent proposal to install filtering software on every new computer sold was roundly rejected by citizens (Lagerkvist 2010). On China's Sina Weibo (a social network site akin to Twitter), netizens - a term created to describe China's unique culture of web activists - openly acknowledge their suspicions of the state information apparatus, referring to questionable CPI (consumer price index) figures as "Com[ing] from Person's Imagination" (Inocencio 2011). Indeed, Internet users in China believe - to a much higher extent than observed elsewhere around the world-that the Internet will give them a greater understanding of politics as well as more say in what the government does (Zheng and $\mathrm{Wu} 2005$ ).

This growing comfort with resistance and distrust of official government positions are already demonstrating very real effects in everyday life. For example, after one man was entrapped by local police near Shanghai, netizens demanded an investigation, and when the original investigation suggested that the police had done nothing wrong, the netizens' response prompted a new investigation and the ultimate clearing of the man's record (Richburg 2009). More recently, in response to silence from China's Railways Ministry after a deadly high-speed train crash and apparent efforts to cover up the accident by burying the wreckage, netizens forced a full investigation and the reversal of an earlier decision prohibiting victims from filing lawsuits. Beijing professor Zhan Jiang has referred to this as the "microblogging revolution" (cited in Wines 2009). Citizens reflect on this new relationship to government as well: "With just one person's efforts, [conditions] wouldn't change [...] but with the power of the Internet, things will be different" (Richburg 2009).

\subsection{Efficiencies in Local Relationships among Individuals and Non-Governmental Organizations}

When governing bodies are not judged to be fulfilling their duties, new technologies provide the means for networking, organizing, and fomenting resistance. One of the more ironic examples has been the "global grassroots", 
anti-globalization movement's use of the Internet and cell phones in organizing mass street demonstrations protesting virtually every international G-8, IMF, and World Bank conference in recent years (Sachs 2005). Yang (2009) argues that technology-supported transnationalism has facilitated the activism because of several features: it expands the scope of some issues and invites wider audiences; can involve transnational strategies; and can involve targets and actors situated in different geographic spaces. Such technologies have the potential to provide persons living under oppressive regimes with outside ideas (Madon 2000). Local abuses in human rights can be reported to networked human rights groups, who can apply external pressure to resolve a situation (Metzl 1996; Keck and Sikkink 1997; Labiad 2006), as happened in China in 1989 and the Soviet Union in 1990 (Frederick 1993).

To provide a more recent detailed case, and the most significant social resistance movement in China since 1989, the spiritual-religious group Falun Gong has been the subject of increasing suppression from the Chinese central government. When the movement was outlawed in 1999, leaders turned primarily to overseas networks to maintain communication among members and produce alternative media content, culminating in large-scale protests and the hacking of state-run television in 2002 (Zhao 2003). Although media coverage has waned, the group continues to generate enough international coverage to periodically put pressure on the central government. As noted above, such connections are not made without difficulty, however. Morozov (2011) notes that Internet-based networks bring with them increased visibility, putting dissidents at pronounced risk of government backlash.

Although the government is able to censor messages sent through email and cell phones, the true democratic potential of new technologies may lie in their ability to organize people on mass scales (Rowen 2007). As people gain more access to more information and an awareness of conditions within and outside the country, they inevitably demand increased rights (Rowen 2007). Thus, new media and technologies increase people's access to information, as well as make it more difficult for governments to violate a person's rights without going unnoticed.

In addition, as observed in many of the recent political movements and popular uprisings throughout the Arab world, these technologies can connect persons with other local actors, resulting in greater local capacity for civic participation. The Internet can spur greater contention, in Yang's (2009) terms, by promoting contentious conversations among people; connecting various organizational bases and actors; and allowing them to be more responsive to instances of injustice. The role of social capital, or the norms of reciprocity and mutual trust in civil society that facilitate cooperative action among networks 
of citizens and local organizations, in promoting democratization in China (Xu et al. 2010) and elsewhere has also received much attention of late. Indeed, the function of Internet use and other communication technologies in facilitating both informal and formally organized "bonding and bridging" ties (Hampton and Wellman 2003; Hoffman and Appiah 2008; Wellman et al. 2001) deserves much more attention outside North America, particularly as those technologies spread and change so rapidly.

ICT regularly connects NGOs, helping them form local alliances, as well as link them with charitable organizations in other countries (Madon 2000). A recent study in China found that $80 \%$ of civic associations were connected to the Internet, and two-thirds had homepages (Yang 2009). Because governments are generally unable to coalesce all of the various skills, technologies, persons, and expertise needed to address a given problem, greater use of technologies allows networks of organizations to develop to meet local needs (Ndou 2004). Electronic networks may help alleviate food insecurity by linking farmers, workers, researchers, organizations and associations in attempts to ease competition for resources (Kaimowitz 1993; Madon 2000), for instance. Both successes and failures can be shared within these networks, strengthening individual actors as well as entire communities (Keniston 2004). In addition, persons with technological training are freed to collaborate for productive purposes with persons nearby as well as those far away; the benefits of such collaboration need not necessarily exit the local space but can instead result in increased local capacity for production of goods and knowledge (Harris 2004). For example, large numbers of villagers in the rural China Internet project cited earlier (Ulrich 2004) used the new technology to locate local business partners as well as to communicate with people outside their village, fostering the potential for development and change in very local ways in developing countries.

Finally, evidence from China suggests that ICT is being used to connect people for explicitly political purposes. Yang (2009) provides an example of how netizens mobilized to defend a college student who had been expelled because of health conditions. The student had posted about his dilemma in an online forum, and the members mobilized and pressured the university to reverse its decision. In another example, after a migrant worker was brutally killed by police in Guangdong, China, ICT-based networks were used to transmit information about his death both to the nearby migrant community and back to his hometown (Chiu 2009). In both cases, ICT facilitated the development of rapid response networks among friends, peers, and family members, and then back to journalists. Moreover, these kinds of actions also have the potential to push back against social stigma, in these cases, resulting from health, social class, and geographic origin. 


\subsection{Efficiencies in Work and the Transformation of Traditional Roles}

Finally, the transformation of developing economies has necessarily been accompanied by a transformation of economic activities at more local levels. Such technologies connect excluded persons to markets, and therefore restructure them (although they do not necessarily transform them, as discussed earlier) (Bebbington 1996). A new social networking site in India allows "mentors" to create profiles for lower SES persons who lack such access, allowing them to be located for jobs, as well as incorporating them into a larger economic network (Kumar at al. 2008). Cell phones obviously have the potential to connect small laborers and businesses with other entities seeking their work, granting them more agency in local markets (Kumar et al. 2008), and their growth has also been remarkable in China (Guthrie 2005). ICT may also enable small retailers to organize and form collectives in response to the intrusion of large multinational firms into developing economies; doing so increases their bargaining power and allows them to more effectively compete against these giants (Kumar et al. 2008). ICT may help reduce inequality by linking persons with larger markets, as has been demonstrated with farmers in Shandong who created a website to connect to more international clients (Zhu 2006). The blend of new technologies with traditional technologies and production processes allows for a dynamic, more efficient production. Technologies have the ability to increase capacity, by extending one's possible resources, as well as capability, by improving performance as a result of this increased capacity (Platt and Wilson 1999). As technologies have increased the efficiencies in communication among local persons, organizations, and governments, they have also increased efficiencies in other tasks. In rural spaces, the introduction of technology can result in more efficient production techniques, thereby increasing the possibility of engaging in other, potentially emancipatory, activities.

For example, the introduction of technology may result in increased efficiencies that help challenge traditional behavioral roles, such as those proscribed by gender. Rural electrification greatly reduces the time required for household tasks (Reiche et al. 200o), such as that required for pumping water and collecting fuel; electricity also extends the day, allowing women more time for their own activities (assuming the extra time is not loaded with additional household tasks). Similarly, new information and communication technologies decrease the time required for travel in order to communicate or purchase goods; enable greater awareness of markets and prices; increase access to emergency and other health care; and help gather information and learn about regional educational opportunities (Aitkin 1998). Such technologies build upon 
the increased efficiencies that came with telephone lines, because wireless technologies reduce the need for such large infrastructure investments. As a result, women become less dependent on male partners, governments, and charity for support and thereby have more control over their lives. In India, rural electrification was shown to increase the amount of time women spent reading (Reiche et al. 2000).

In Oaxaca, the introduction of technology into household production systems may make women's work more efficient; these efficiencies open up the possibility of creating separate, alternative spaces, such as co-ops, to challenge their traditional exclusion from markets and productive activities (Mutersbaugh 1998). Several projects have challenged this exclusion directly; for example, in Guyana, a telecommunications company provided a women's collective computer equipment and free Internet access, allowing them to market their wares on a global scale (Leahy and Yermish 2003). In Bangladesh, Grameen has created a program in which women oversee local cell phone operation in rural villages; for small fees, villagers use their cell phones, inserting women into the core of local economies and granting them freedom from traditional roles defined by gender (Leahy and Yermish 2003).

Soriano (2007) emphasizes that enhanced ICT access in rural areas carries with it not just economic benefits, but also leads to enhancements in human and social dimensions. For instance, in a study of rural Chinese ICT centers, she found that greater access to information on market prices and farming practices led not just to greater incomes, but also encouraged farmers to consider a range of new livelihood strategies, many of which involved less intensive work but higher profit margins. In many cases, the telecenters themselves became sites of training that offered greater social mobility; they also served as new venues for sharing knowledge, transforming traditional social roles in the process.

Some caution about the potential transformation of economic relationships must be expressed, though. The optimism for greater agency in production is balanced by evidence that, although globalization potentially employs more people in developing countries, it may do so by stripping them of traditional rights; further, without explicit attention, it simply replicates existing hierarchies. This can also happen in post-industrial countries if technology policies themselves are not developed through flexible, transparent, and democratic institutional processes (Monahan 2004). Further, the still-prohibitive cost of some communication technologies likely excludes women before it does so with men. To the extent that men are favored for schooling over women, and technology fluency is acquired in formal settings, women are likely to remain disadvantaged (Leahy and Yermish 2003). A project in rural China found, for 
instance, that women were less aware of and used community Internet centers less frequently than did male villagers (Ulrich 2004). Even in developmentoriented NGOs, males may be more likely to use telecommunication technologies than women (Aitkin 1998).

\section{Conclusion}

Technologies, to the extent that they can escape mass-oriented, dehumanizing valences, and instead enable local and individual creativity and modification, can undoubtedly improve the quality of human life (Schumacher 1973). Whereas globalization has clearly resulted in the exploitation of persons, spaces, and resources in developing countries, its effects can ultimately be empowering if it results in greater democratization through increased access to knowledge; accountability and responsiveness to government; more effective, immediate, and widespread communication among citizens and political organizations; and more equitable work, gender, and other roles within and across political borders. The real potential of the spread of communication technologies rests not singly in their creation of global networks and modes of production, but in their transformation of local, more proximal, ways of living and knowing. If these technologies do not aid in changed, more equitable forms of everyday living, then the relevance of all of their other impressive features and capabilities must be questioned.

The Chinese government has permitted a remarkable growth of ICT, but the sector has been ever carefully managed in ways that promote its economic development impact and simultaneously limit its ultimate transformative potential, socially and especially politically. Where the threats to the central government's rule have been concentrated, it has taken a more restrictive role in ICT, but when the dangers are less evident, such as allowing greater access to other types of information (i.e, health-related), it has at times even encouraged the growth of ICT. This supports Mahmood's (2004) assertion that even minimal democracies can initiate reforms through ICT, particularly when compared to some of the other cases provided here. As China continues to develop rapidly economically but more slowly democratically (e.g., with popular elections of local officials now widespread, and non-Communist-Party candidates but no other political parties allowed), it remains to be seen how ICT will affect the course and pace of democratization in China and elsewhere. For example, at the present stage, such local electoral "campaigns" appear to be brief and decidedly "low tech" (by any standards, much less those in the U.S.), particularly in the still populous rural areas of China but even in urban neighborhoods as well. And even though the popularity of blogs has spurred some 
political action, most tend to focus instead on celebrity culture, sports, and finance (Lagerkvist 2010), suggesting that the increased efficiencies in accessing information and connecting with other individuals have not always translated into action. Nonetheless, evidence suggests that ICT is fundamentally transforming people's relationships to knowledge, government, other actors, and themselves. Chinese youth are growing up with far more access to information than their adult forbearers, and even adults are exhibiting changing expectations of government. Even with continued restrictions on information, their expectations for and relation to information are being fundamentally altered. What seems clear is that ICT will eventually affect the course and likely the pace of political development and do so dramatically, as it has already done in most other countries throughout the globe.

\section{References}

Abbott, Jason P. 2001. “Democracy@internet.asia? The Challenges to the Emancipatory Potential of the Net: Lessons from China and Malaysia." Third World Quarterly 1:99-114.

Addison, Tony, and Almas Heshmati. 2004. "The New Global Determinants of FDI Flows to Developing Countries: The Importance of ICT and Democratization." Pp. 151-186 in Monetary Integration, Markets and Regulations, edited by M. Bagella, L. Becchetti, I. Hasan, and W. C. Hunter. Oxford, UK: Elsevier, Ltd.

Aitkin, Helen. 1998. "Rural Women and Telecommunication in Developing Countries." Proceedings of a Workshop on Women in Agriculture and Modern Communication Technology, Tune, Denmark.

Al-Jaghoub, Saheer, and Chris Westrup. 2006. "Jordan and ICT-led Development: Towards a Competition State?" Information Technology \& People 16:93-110.

Avgerou, Chrisanthi. 2008. "Information Systems in Developing Countries: A Critical Research Review." Journal of Information Technology 23:133-146.

—. 2010. "Discourses on ICT and Development." Information Technologies \& International Development 6(3):1-18.

Backus, Michiel. 2001. E-governance and Developing Countries: Introduction and Examples. The Hague, Netherlands: International Institute of Communication and Development.

Bebbington, Anthony. 1996. "Organizations and Intensifications: Campesino Federations, Rural Livelihoods and Agricultural Technology in the Andes and Amazonia." World Development 24:1161-1177.

Bloomfield, Brian P., and Niall Hayes. 20og. "Power and Organizational Transformation through Technology: Hybrids of Electronic Government." Organization Studies 30(5):461-487.

Blow, Charles M. 2011. "The Kindling of Change." New York Times, February 4, p. A17. Retrieved March 27, 2011 (http://www.nytimes.com/2011/02/05/opinion/o5blow.html?_r=1\&ref=opinion).

Bonder, Gloria. 2002. "From Access to Appropriation: Women and ICT Policies in Latin America and the Caribbean." Export Group Meeting on Information and Communication Technologies and their Impact and Use as an Instrument for the Advancement and Empowerment of Women. Seoul, Republic of Korea.

Bowonder, B., T. Miyqake, and T. M. Singh. 1993. "Emerging Trends in Information Technology: Implications for Developing Countries." International Journal of Information Management 13:183-204. 
Bhuiyan, A. J. M. Shafiul Alam. 2004. "Universal Access in Developing Countries: A Particular Focus on Bangladesh." The Information Society 20:269-278.

Bishop, Bill. 2010. “网瘾战争 War of Internet Addiction"-Are World of Warcraft's Travails in China Much More Interesting than Google's? Digicha: Internet and Digital Media in China, January 24. Retrieved October 31, 2000 (http://digicha.com/index.php/2010/o1/net-addictionwars-are-world-of-warcrafts-travails-in-china-much-more-interesting-than-googles/).

Castells, Manuel. 1999. Information Technology, Globalization and Social Development, Geneva: Nations Research Institute for Social Development.

- 1997. The Power of Identity (The Information Age: Economy, Society and Culture, Vol. 2). Cambridge: Blackwell.

Chaudhry, Basit., Jerome Wang, Shinyi Wu, Margaret Maglione, Walter Mojica, Elizabeth Roth, Sally C. Morton, and Paul G. Shekelle. 2006. "Systematic Review: Impact of Health Information Technology on Quality, Efficiency, and Costs of Medical Care." Annals of Internal Medicine 144:742-752.

China Internet Network Information Center. 2010. "Internet Statistics." Retrieved October 18, 2011 (http://www.cnnic.net.cn/en/index/oO/index.htm).

Chiu, Jack L. 2009. Working-Class Network Society: Communication Technology and the Information Have-Nots in Urban China, Cambridge, Massachusetts: The MIT Press.

Christens, Brian D., and Douglas D. Perkins. 2008. "Transdiscriplinary, Multilevel Action Research to Enhance Ecological and Psychopolitical Validity." Journal of Community Psychology 36(2):214-231.

Drezner, Daniel W. 2005, March. "Weighing the Scales: The Internet's Effect on State-Society Relations." Paper presented at "Global Flow of Information," Yale Information Society Project, Yale Law School in New Haven, Connecticut.

Edejer, Tessa Tan-Torres. 200o. "Disseminating Health Information in Developing Countries: The Role of the Internet." British Medical Journal 321:797-800.

Entous, Adam. 2011. "U.K. Prime Minister Says News Corp. Ties Were Too Cozy." The Wall Street Journal, September 25. Retrieved October 18, 2011 (http://online.wsj.com/article/SB1000142405 297020401060457659320354452656o.html).

Everett, Margaret. 1998. "Latin America On-line: The Internet, Development, and Democratization." Human Organization 57:385-393.

Fang, Lee. 2011. "Yahoo Appears to be Censoring Email Messages about Wall Street Protests. Think Progress, September 20. Retrieved October 18, 2011 (http://thinkprogress.org/media/ 2011/o9/20/323856/yahoo-censoring-occupy-wall-street-protests/).

Feenberg, Andrew. 1990. "The Critical Theory of Technology." Capitalism Nature Socialism $1(5): 17-45$.

Fischer, Edward F. 2001. Cultural Logics \& Global Economies: Maya Identity in Thought \& Practice. Austin, TX: University of Texas Press.

Frederick, Howard. 1993. "Computer Networks and the Emergence of Global Civil Society." Pp. 283-295 in Global Networks, edited by Linda Marie Harasim. Cambridge, MA: The MIT Press.

Freire, Paolo. 1970. Pedagogy of the Oppressed. NY: Continuum.

Freeland, Chrystia. 2011. "Sizing Up Revolutions in Waiting." New York Times, February 24. Retrieved Feb. 25, 2011 (http://www.nytimes.com/2011/02/25/world/middleeast/25iht-letter25. html?_r=1\&scp=1\&sq=revolutionary\%2omeasures\%2ointernet\&st=cse).

Guthrie, Doug. 2005. "Information Technology and State Capacity in China." In Digital Formations: IT and New Architectures in the Global Realm, edited by Robert Latham and Saskia Sassen. Princeton, NJ: Princeton University Press.

Hampton, Keith, and Barry Wellman. 2003. "Neighboring in Netville: How the Internet Supports Community and Social Capital in a Wired Suburb." City \& Community 2(4):277-311. 
Harris, Eva. 2004. "Building Scientific Capacity in Developing Countries. European Molecular Biology Organization Reports 5:7-11.

Heeks, Richard. 2002. "Information Systems and Developing Countries: Failure, Success, and Local Improvisations.” The Information Society 18:101-112.

Hill, David T., and Krishna Sen. 2005. The Internet in Indonesia's New Democracy. New York: Routledge.

Hoffman, Lindsay H., and Osei Appiah. 2008. "Assessing Cultural and Contextual Components of Social Capital: Is Civic Engagement in Peril?” The Howard Journal of Communications 19(4):334354.

Holton, Robert. 200o. "Globalization's Cultural Consequences.” The Annals of the American Academy of Political and Social Science 570:140-152.

Inocencio, Ramy. 2011 “China Netizens Protest Rising Prices.” CNN Business36o, May 12. Retrieved October 13, 2011 (http://business.blogs.cnn.com/2011/05/12/china-netizens-protest-consumerprices/).

Joyce, Mary C. 2010. "Chinese Censorship and the Philosophy of Language.” Meta-Activism Project: Making Digital Activism Smarter. November 7. Retrieved March 27, 2011 (http://www. meta-activism.org/2010/11/chinese-censorship-and-the-philosophy-of-language/)

—. 2011. "Net Delusion'" Review: The Authoritarian Tinity and the Return to the Cold War." Owni.eu: Digital Journalism. February 25. Retrieved March 27, 2011 (http://owni.eu/?p=35634).

Juris, Jeffrey S. 2008. Networking Futures: The Movements against Corporate Globalization. Durham, NC: Duke University Press.

Kahn, Richard, and Douglas Kellner. 2007. "Paolo Freire and Ivan Illich: Technology, Politics and the Reconstruction of Education." Policy Futures in Education 5(4):431-448.

Kaimowitz, David. 1993. "The Role of Nongovernmental Organizations in Agricultural Research and Technology Transfer in Latin America." World Development 21:1139-1150.

Keck, Margaret E., and Kathryn Sikkink. 2007. "Environmental Advocacy Networks. Pp. 370-393 in The Globalization and Development Reader, edited by J. Timmons Roberts and Amy Bellone Hite. Malden, MA: Blackwell.

Keniston, Kenneth. 2004. "The Four Digital Divides.” Pp. 11-36 in IT Experience in India: Bridging the Digital Divide, edited by Kenneth Keniston and Deepak Kumar. New Dehli: Sage Publications India.

Kumar, Arun, Nitendra Rajput, Sheetal Agarwal, Dipanjan Chakraborty, and Amit Anil Nanavati. 2008. "Organizing the Unorganized: Employing IT to Empower the Under-Privileged." Proceedings of the 17 th International Conference on the World Wide Web. Beijing, China.

Labiad, Nour-eddine. 2006. "The Internet and “The Great Firewall of China” Dialogues@RU 5:45-55. Retrieved October 13, 2011 (http://dialogues.rutgers.edu/vol_05/essays/documents/Labiad.doc).

Lagerkvist, Johan. 2010. After the Internet, Before Democracy: Competing Norms in Chinese Media and Society. Bern: Peter Lang.

Leahy, Kimberly Betz, and Ira Yermish. 2003. "Information and Communication Technology: Gender Issues in Developing Nations.” Informing Science Journal 6:143-155.

Li, Quan, and Adam Resnick. 2003. "Reversal of Fortunes: Democratic Institutions and Foreign Direct Investment Inflows to Developing Countries." International Organization 57:175-211.

MacAskill, Ewan. 2007. "CIA Spy Says Cover Blown by Own Side." The Guardian, March 16. Retrieved October 18, 2011 (http://www.guardian.co.uk/world/2007/mar/17/usa.ewenmacaskill).

Madon, Shirin. 200o. "The Internet and Socio-Economic Development: Exploring the Interaction." Information Technology \& People 13(2):85-101.

Mahmood, Rumel. 2004. "Can Information and Communication Technology Help Reduce Corruption? How So and Why Not: Two Case Studies from South Asia." Information and Communication Technology 3(3):347-373. 
Metzl, Jamie F. 1996. "Information Technology and Human Rights." Human Rights Quarterly 18:705-746.

Ministry of Industry and Information Technology of People's Republic of China, 2008. “2008 年 12 月通信业主要指标完成情况.” Retrieved October 18, 2011 (http://www.miit.gov.cn/n11293472/ n11295057/n11298508/1191266o.html).

Mitter, Swasti, and Sheila Rowbotham. 200o. "Bringing Women's Voices into the Dialogue on Technology Policy and Globalization in Asia." International Feminist Journal of Politics 2:382-401.

Monahan, Torin. 2004. "Technology Policy as a Stealth Agent of Global Change." Globalisation, Societies and Education 2(3):355-376.

Moore, James C. 2004. "Not Fit to Print: How Ahmed Chalabi and the Iraq War Lobby Used New York Times Reporter Judith Miller to Make the Case for Invasion." Salon, May 27. Retrieved October 18, 2011 (http://www.salon.com/2004/05/27/times_10/singleton/).

Morozov, Evgeny. 2011. The Net Delusion: The Dark Side of Internet Freedom. NY: Public Affairs.

Mutersbaugh, Tad. 1998. “Women's Work, Men's Work: Gender, Labor Organization, and Technology Acquisition in a Oaxacan Village." Environment and Planning D: Society and Space 16:439-458.

Ndou, Valentia Dardha. 2004. "E-government for Developing Countries: Opportunities and Challenges." The Electronic Journal on Information Systems in Developing Countries 18:1-24.

Platt, Louise, and Gordon Wilson. 1999. "Technology Development and the Poor/Marginalized: Context, Intervention, and Participation.” Technovation 19:393-401.

Reiche, Kilian, Alvaro Covarrubias, and Eric Martinot. 2000. "Expanding Electricity Access to Remote Areas: Off-grid Rural Electrification in Developing Countries." Pp. 52-6o in World Power, edited by G. Isherwood. London: Isherwood Production Ltd.

Richburg, Keith B. 2009. “China's 'Netizens' Holding Officials Accountable.” The Washington Post, November 9. Retrieved October 13, 2011 (http://www.washingtonpost.com/wp-dyn/content/ article/2009/11/08/AR2009110818166.html).

Rowen, Henry S. 2007. "When Will the Chinese People be Free?" Journal of Democracy 18(3):38-52.

Sachs, Jeffrey D. 2005. The End of Poverty: Economic Possibilities for our Time. New York: Penguin Press.

Saidi, Nasser, and Hala Yared. 2002. "eGovernment Technology for Good Governance, Development and Democracy in the MENA Countries." Proceedings from Mediterranean Development Forum IV: Fostering Digital Inclusion: The Role of ICT in Development.

Schroth, Peter W., and Preeti Sharma. 2003. "Transnational Law and Technology as Potential Forces against Corruption in Africa." Management Decision 41:296-303.

Schumacher, E. F. 1973. Small is Beautiful: Economics as if People Mattered. London: Blond \& Briggs.

Seifert, Jeffrey W., and R. Eric Petersen. 2002. "The Promise of All Things E? Expectations and Challenges of Emergent Electronic Government." Perspectives on Global Development and Technology 1(2):193-212.

Shirazi, Farid, Ojelanki Ngwenyama, and Olga Morawczynski. 2011. "ICT Expansion and the Digital Divide in Democratic Freedoms: An Analysis of the Impact of ICT Expansion, Education and ICT Filtering on Democracy." Telematics and Informatics 27:21-31.

Silva, Leiser, and Chris Westrup. 2009. "Development and the Promise of Technological Change." Information Technology for Development 15(2):59-65.

Sorriano, Cheryll R. S. 2007. "Exploring the ICT and Rural Poverty Reduction Link: Community Telecenters and Rural Livelihoods in Wu'an, China." The Electronic Journal on Information Systems in Developing Countries 32:1-15.

Stiglitz, Joseph E. 2003. "Globalization, Technology, and Asian Development." Asian Development Review 20(2):1-18.

Stout, Kristie Lu. 2010. "Chinese Netizens Stage Virtual Protest." CNN Business36o, February 11. Retrieved October 13, 2011 (http://business.blogs.cnn.com/2010/02/11/chinese-netizens-stagevirtual-protest/). 
Ulrich, Paul. 2004. "Poverty Reduction through Access to Information and Communication Technologies in Rural Areas: An Analysis of the Survey Results from the Social Impact Assessment Conducted by the Chinese Ministry of Science \& Technology and the United Nations Development Program." The Electronic Journal on Information Systems in Developing Countries 16(7):1-38.

Wang, Chunzhi, and Benjamin Bates. 2008, July 20-25. "Online Public Sphere and Democracy in China." Paper presented at the International Association for Media and Communication in Stockholm, Sweden.

Warschauer, Mark. 2000. "Language, Identity, and the Internet." Pp. 151-170 in Race in Cyberspace, edited by Beth E. Kolko, Lisa Nakamura, and Gilbert B. Rodman. London: Routledge.

Wellman, Barry, Anabel Quan Haase, James Witte, and Keith Hampton. 2001. "Does the Internet Increase, Decrease, or Supplement Social Capital? Social Networks, Participation, and Community Commitment." American Behavioral Scientist 45(3):436-455.

Williams, Kate, and Hui Yan. 2009. "Toward Global Measurement of the Information Society: A U.S.China Comparison of National Government Surveys." First Monday 14(10). Retrieved October 11, 2011 (http://firstmonday.org/htbin/cgiwrap/bin/ojs/index.php/fm/article/view/2576/2306).

Wilson, III, Ernie. J. 2009. "Digital Media, Modern Democracy, and Our Truncated National Debate. Pp. 29-40 in ... And Communications for All: A Policy Agenda for a New Administration, edited by A. M. Schejter. Lanham, MD: Rowman \& Littlefield.

- 2004. "Strategic Restructuring in China." Pp. 223-298 in The Information Revolution and Developing Countries. Cambridge, MA: The MIT Press.

Wines, Michael, and Sharon LaFraniere. 2011. "In Baring Facts of Train Crash, Blogs Erode China Censorship.” New York Times, July 29, A1. Retrieved October 13, 2011 (http://www.nytimes. com/2011/o7/29/world/asia/29china.html?scp=2\&sq=china\%2oblogs\&st=cse).

$\mathrm{Xu}$, Qingwen, Douglas D. Perkins, and Julian Chun-Chung Chow. 2010. "Sense of Community, Neighboring, and Social Capital as Predictors of Local Political Participation in China." American Journal of Community Psychology 45(3-4):259-271.

Yang, Guobin. 2009. The Power of the Internet in China: Citizen Activism Online. New York: Columbia University Press.

Ya'u, Y. Z. 2004. “The New Imperialism \& Africa in the Global Electronic Village.” Review of African Political Economy 99:11-29.

Zhao, Yuezhi. 2003. "Falun Gong, Identity, and the Struggle over Meaning Inside and Outside China." In Contesting Media Power: Alternative Media in a Networked World, edited by Nick Couldry and James Curran. Lanham, MD: Rowman \& Littlefield Publishers, Inc.

Zheng, Yingqin. 2005. "Information Culture and Development: Chinese Experience of e-health." Proceedings of the 38 th Hawaii International Conference on System Sciences.

Zheng, Yongnian, and Guoguang Wu. 2005. "Information Technology, Public Space, and Collective Action in China." Comparative Political Studies 38(5):507-536.

Zhu, Yi. 2006. "Innovation Systems for ICT: The Case of China." Pp. 84-117 in Bridging the Digital Divide: Innovation Systems for ICT in Brazil, China, India, Thailand, and Southern Africa, edited by A. Baskaran and M. Muchie. London: Adonis \& Abbey. 